\title{
Continuity through Renewal: John Dewey, the International Institute in Spain, and Resisting the Assault on the Humanities
}

\section{Andrew Bennett}

The International Institute in Spain 


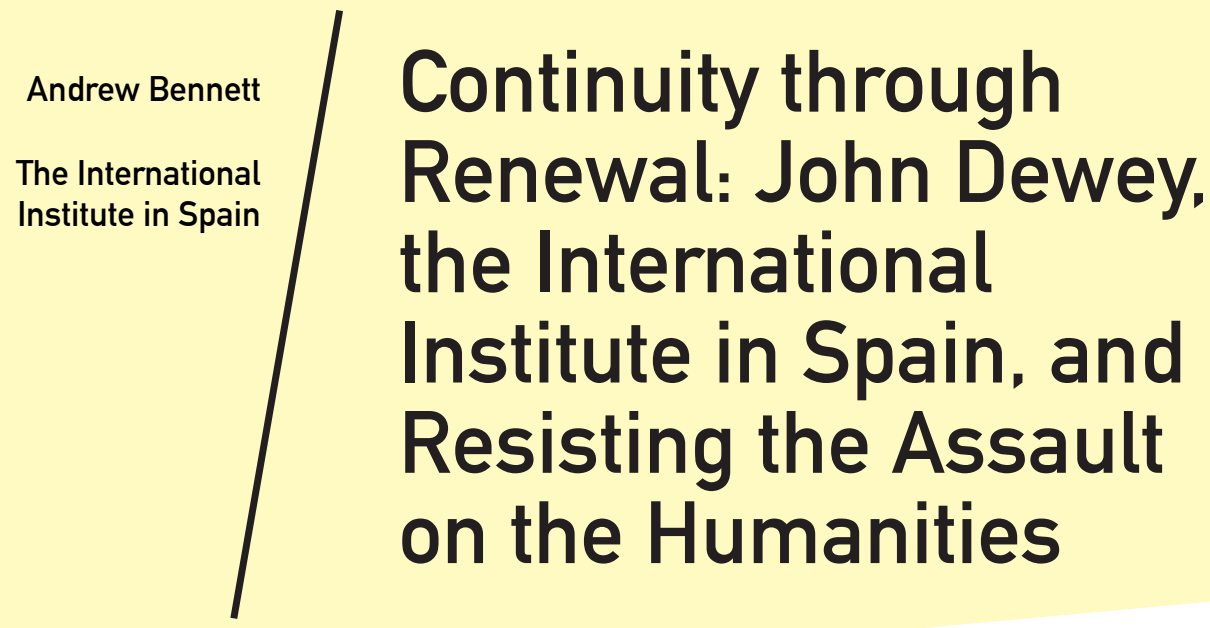

his paper marks the relation between humanities education and democracy as one of mutual necessity, since the pragmatic value of each is dependent on the other to be recognizable and realizable. Such an understanding is drawn from the ideas of the American philosopher and educator John Dewey. Dewey's system clearly reveals the nature of the stakes of the assault on the humanities; it also indicates the educational measures democratic societies should take in response. By instantiating the "conjoint communicated experience" of democracy in a public, shared space in which differences are respected, human meanings are explored, and the expansion of knowledge and experience is valued as an end in itself, the humanities classroom emerges as a site of social renewal, as well as one of resistance to illiberalism. In order to present such a site in a manner befitting Dewey's pragmatism, a lesser-known, local example of the value of humanities education is examined in this paper: that of the International Institute in Spain, located in Madrid. Beginning with its founding as a school for girls by Boston missionaries in 1892, and through its role at the center of

\footnotetext{
Andrew Bennett is the director of the American Cultural Studies Program at the International Institute in Madrid, Spain. He received his doctorate in Comparative Literature from the University of Texas at Austin (USA) in 2013. His dissertation, entitled "Waiting for Virgilio: Reassessing Cuba's teatro del absurdo," argues for the historical legitimacy of the theatre of the absurd in Cuba due to its power as a medium of political dissent in the post-revolutionary era and beyond. He has published articles in journals like Cuadernos Americanos and Journal of Beckett Studies, among others. He lives in Madrid, where he teaches classes in U.S. cultural studies and literature at the International Institute and the Universidad Carlos III de Madrid.
}

Bennett,Andrew."Continuity through Renewal: John Dewey, the International Institute in Spain, and Resisting the Assault of the Humanities". REDEN, vol. 2, no.1,2020, pp. 23-38.

Recibido: 10 de diciembre de 2019. 
a network of institutions invested in progressive educational reform in Spain during the pre-civil war period, IIE stands as a testament to the continuity through renewal that defines both liberal democracy and humanities education.

Key Words: Humanities; John Dewey; democracy; education; International Institute in Spain; Institución Libre de Enseñanza; multiculturalism; progressivism.

A 2013 article published by the New York Times entitled "Humanities Studies Under Strain Around the Globe" paints a bleak picture for those invested in the liberal arts:

In the global marketplace of higher education, the humanities are increasingly threatened by decreased funding and political attacks. Financing for humanities research in the United States has fallen steadily since 2009, and in 2011 was less than half of one percent of the amount dedicated to science and engineering research and development. This trend is echoed globally: According to a report in Research Trends magazine, by Gali Halevi and Judit Bar-Ilan, international arts and humanities funding ha been in constant decline since 2009. (Delany)

The article goes on to describe the logic employed by some of those responsible for these funding cuts by quoting the official language of their budget recommendations. Rick Scott, Governor of the state of Florida, proposed that "students majoring in liberal arts and social science subjects should pay higher tuition fees, arguing they were 'nonstrategic disciplines"' In its own report regarding the state of the humanities released in 2013, quoted in the article, the American Academy of Arts and Sciences calls for humanities researchers and practitioners to be more vocal in defending their work, and more assertive in defining its value:

At a time when economic anxiety is driving the public toward a narrow concept of education focused on short-term payoffs, it is imperative that colleges, universities, and their supporters make a clear and convincing case for the value of liberal arts education. (Delany)

The humanities, according to its critics, are useless. But who determines their utility? According to what system of value are they being judged? And what, if anything, is different about the stakes of the current debate? After all, Jack Kaminsky, writing in 1956, called attention to a similar value system at work in the academy:

Science is what a man must have if he is to better himself; art is what a man may have if he has the time. The arts, therefore, are to be regarded as no more than simple amusements that men might turn to in their spare moments. Science is necessary; art is contingent. (66)

While the market is not generous with humanists, the current assault on the humanities, their devaluation in both material and moral terms, is not simply a product of brute economic forces, or of an entrenched utilitarianism. Rather, it is another front in a larger war, not against the humanities in particular, but against liberal humanism in general. Though it might at first seem as though the 


\section{Liberal democratic principles like equality. empathy, and freedom are only recognized and deemed valuable from a humanistic perspective. Without the humanities, without humanists. democracy itself has no defenders.}


conversation surrounding this topic has changed little over the past half-century, the truth is that reality has finally overtaken hyperbole. Or, to put it another way: a conversation that was once largely academic is so no longer.

The value of the humanities in a social sense has been made painfully evident in recent years, as the collective consensus by which the veracity of shared experience is confirmed has been shaken. The "post-truth," "fake news" era is, if nothing else, a testament to the utility of critical interpretative and communicative skills, which form the foundation of humanities education. But it is also a testament to the power of the presuppositions that undergird those skills and the civic actions they are expected to guide, as well as to the need to affirm those presuppositions explicitly, as valuable in and of themselves. Liberal democratic principles like equality, empathy, and freedom are only recognized and deemed valuable from a humanistic perspective. Without the humanities, without humanists, democracy itself has no defenders.

This paper marks the relation between humanities education and democracy as one of mutual necessity, since the pragmatic value of each is dependent on the other to be recognizable and realizable. Such an understanding is drawn from the ideas of the American philosopher and educator John Dewey, in particular those expressed in Democracy and Education. Dewey's system clearly reveals the nature of the stakes of this assault; it also indicates the educational measures democratic societies should take in response. By instantiating the "conjoint communicated experience" of democracy in a public, shared space in which differences are respected, human meanings are explored, and the expansion of knowledge and experience is valued as an end in itself, the humanities classroom emerges as a site of social renewal, as well as one of resistance to illiberalism. In order to present such a site in a manner befitting Dewey's pragmatism, a lesserknown example of the value of humanities education will be presented: that of the International Institute in Spain, located in Madrid. Beginning with its founding as a school for girls by Boston missionaries in 1892, through its role at the center of a network of institutions invested in progressive educational reform in Spain during the pre-civil war period, and continuing on to its present-day iteration as a site for transnational learning and public encounters with North American culture, IIE stands as a testament to the continuity through renewal that defines both liberal democracy and humanities education.

For Dewey, a constructive, communicative exchange between individuals from different backgrounds, all of them invested in a common project that exceeds their own self-interest, is the primary condition for making democracy manifest. As Ignacio Pérez-Ibáñez notes in his article "Dewey's Thoughts on Social Change," in Democracy and Education Dewey makes the case that "a democracy is a progressive society that facilitates communication, co-operation, and respect between people of different groups" (Pérez-lbáñez 25). The ability of individuals and groups to overcome differences and navigate towards shared objectives is, according to Dewey, inculcated to a significant degree in the classroom, where these behaviors are modeled and their meanings are explicated. The recognition of meaning is a key point in Dewey's philosophy, since without some awareness of the reason these subjects are taught in the first place a student's education is 
degraded to simple imitation, to rote memorization without any discernible objective. For Dewey, art and literature provide that necessary communicative meaning, since they:

[D]o more than all else to determine the current direction of ideas and endeavors in the community. They supply the meanings in terms of which life is judged, esteemed, and criticized. For an outside spectator, they supply material for a critical evaluation of the life led by that community. (Experience and Nature 204)

Meaning and meaning creation are for Dewey wholly humanistic endeavors. Humanities education, then, can be understood as learning practices that synthesize and communicate the critical appreciation of human meaning at both a cultural and trans-cultural level with democratic norms of interaction, as group identities are registered, criticized, and compared. The benefit of the guided recognition and appreciation of human achievement from within one's group, coupled with a simultaneous fostering of respect and identification with the achievements and meanings generated by other groups, is the instantiation of Dewey's democratic ideal, as expressed in Democracy and Education:

A democracy is more than a form of government; it is primarily a mode of associated living, of conjoint communicated experience. The extension in space of the number of individuals who participate in an interest so that each has to refer his own action to that of others, and to consider the action of others to give point and direction to his own, is equivalent to the breaking down of those barriers of class, race, and national territory which kept men from perceiving the full import of their activity. (91)

For most of the $20^{\text {th }}$ century, the democratic habits instantiated in humanities education in progressive schools in the United States subsequently informed a lifetime of public community engagement afterwards. However, the decline of American civic life in the latter half of the $20^{\text {th }}$ century, coupled with the rise of the Internet and the digital enclaves it has fostered, has severely weakened our ability to create "our sense of the 'public'-the space where we address the problems that transcend our niches and narrow self-interests"; that is to say, the conditions for a functioning democracy (Pariser 17).

The above quote is taken from Eli Pariser's The Filter Bubble(2011), which argues that one of the primary social impacts of the Internet has been to deplete the "bridging capital" necessary to move between enclaves and overcome individual differences in the interest of common cause. The term "bridging capital “comes from Robert Putnam's Bowling Alone (2000), a seminal sociological work that diagnoses the disintegration of American social structures from the 1960s to the turn of the century. Taken together, these two analyses of contemporary American society, both of which cite Dewey's influence extensively, reveal breakdowns in its communal foundation that retroactively prove the necessity of those principles proposed in Democracy and Education more than one hundred years ago. As Dewey's work claims, in order to repair that foundation we must recognize the heterogeneous and multicultural humanities teaching environment as the primary institutional force capable of ensuring that liberal democratic values are enacted and continually renewed. 
Bowling Alone interrogates the notion of social capital, generally understood to refer to the value of social networks, and seeks to add nuance to its usage. Putnam distinguishes between bonding (or exclusive) capital and bridging (or inclusive) capital:

Some forms of social capital are, by choice or necessity, inward looking and tend to reinforce exclusive identities and homogenous groups. Examples of bonding social capital include ethnic fraternal organizations, church-based women's reading groups, and fashionable country clubs. Other networks are outward looking and encompass people across diverse social cleavages. Examples of bridging social capital include the civil rights movement, many youth service groups, and ecumenical religious organizations. (22)

Both bonding and bridging social capital are crucial resources in the development of a functioning participatory democracy, as Putnam makes clear. In order to develop and maintain civic engagement, civic platforms (churches, voluntary associations, etc.) for engagement must exist. Putnam quotes Dewey in support of this idea: "Fraternity, liberty and equality isolated from communal life are hopeless abstractions... Democracy must begin at home, and its home is the neighborly community" (337). Bowling Alone charts the fragmentation of this "neighborly community" through the erosion of social capital, and locates the value of bridging capital at the foundational level of democracy:

Where people know one another, interact with one another each week at choir practice or sports matches, and trust one another to behave honorably, they have a model and a moral foundation upon which to base further cooperative enterprises. (346)

While this common "moral foundation" is strengthened and stabilized through its employment via participatory democracy, it is continually renewed over the course of the individual's educational development, both in and out of the classroom, throughout a lifetime.

As Putnam's work makes abundantly clear, the depletion of America's social capital was an entrenched reality well before the Internet rose to prominence. However, the arrival of the digital age has accelerated the process, and added dimensions to its outcomes that few foresaw. Pariser evokes "bridging capital" in particular in his text in order to describe the social costs of, not simply Internet culture, but the structures that manage and control user interface online:

The basic code at the heart of the new Internet is pretty simple. The new generation of Internet filters looks at things you seem to like-the actual things you've done, or the things people like you like-and tries to extrapolate. They are prediction engines, constantly creating and finding a theory of who you are and what you'll do and want next. Together, these engines create a unique universe of information for each of us-what l've come to call a filter bubble-which fundamentally alters the way we encounter ideas and information. (9)

Pariser's "filter bubble" is, crucially, a product of anticipatory marketing that guides interface, and is not exclusively of the Internet user's choosing. However, the digital tools that dictate interface are predicated on a psychological reality: given a choice between two social groups, an individual will be drawn to associate with that group whose identity and preferences mirror their own. This homophily is exponentially increased online, where users have the freedom to pursue niche 
interests and develop relationships within subgroups in a virtual space that is neither fully public nor fully private. As Pariser points out, the initial hope for the Internet was that it would amplify, rather than drain, our bridging capital, and make a globalized world more neighborly:

\begin{abstract}
But that's not what's happening. Our virtual next-door neighbors look more and more like our real-world neighbors, and our real-world neighbors look more and more like us. We're getting a lot of bonding but very little bridging. [...] In a personalized world, important but complex or unpleasant issues [...] are less likely to come to our attention at all.As a consumer, it's hard to argue with blotting out the irrelevant and unlikeable. But what is good for consumers is not necessarily good for citizens. What I seem to like may not be what I actually want, let alone what I need to know to be an informed member of my community or country. (17-18)
\end{abstract}

The fact that information flow itself has been weaponized in attacks on democratic institutions in the United States and beyond, and that many of these attacks have been successful to varying degrees, should come as little surprise given the confluence of factors presented here. Atomized individuals have sealed themselves, intentionally or not, within homogenizing filter bubbles that determine their virtual communities. These communities are defined not by how they negotiate difference, but how they accentuate sameness. As such, the spaces between enclaves grow larger, and mutual suspicion and distrust is the result. As consumers of information guided by homophily in their choice of content, these individuals are operating outside of, to quote Dewey, the "conjoint communicated experience" of democracy.

These communities are defined not by how they negotiate difference, but how they accentuate sameness. As such, the spaces between enclaves grow larger, and mutual suspicion and distrust is the result. As consumers of information guided by homophily in their choice of content, these individuals are operating outside of, to quote Dewey, the "conjoint communicated experience" of

democracy.

It would require too great a digression to engage adequately with the facts of the "Fake News" phenomenon and index the political machinations behind it, from all of the relevant perspectives. Simply put, the extreme U.S. political polarization of the past thirty years has been amplified by the proliferation of online news content that is guided by market objectives, rather than liberal democratic ones. The need to generate clicks and user engagement means, to echo Pariser, giving people what they want rather than what they need from a civic perspective. This directive has led to a profound divergence in the perception of political reality, as the partisan filter bubbles shape truths rather than the other way around. Truth itself has become a product of intra-bubble consensus. Those truths that depart from the narrative consensus of one's respective bubble are marked as "fake news," and are attacked as such. This "post-truth" discourse is perceived 
nearly uniformly (at least by humanists) as an existential threat to both liberal and humanistic values. For a constellation of disciplines committed to pursuing and disseminating truth, the discreditation of that pursuit, or the rejection of its authority or any claim to expertise, certainly qualifies as an open declaration of hostilities.

Humanities education, and education in general, is for Dewey a tool by which society can ensure the proper transfer of knowledge and meaning from one generation to the next. That is to say, it is a manifestation of social survival in an evolutionary sense. The disruption of that transfer, then, is tantamount to social suicide. Dewey's ideas help clarify the stakes in this debate, and to better understand how the current crisis has come to be. His pragmatism also serves to chart a path forward, since it obliges us to answer a simple question: How do we fix the problem for the future? How do we turn back the assault?

A pragmatic question deserves a pragmatic answer, one consistent with its premises. Rather than appeal to transcendent values, in Dewey's system the justification for championing a democratic society is equivalent to the recognition of that society's defining features, which in turn are equivalent to the manner in which such a society's wealth of knowledge is expanded and maintained. The worth of democracy as a social system is based on the fact that such a system allows for different social groups within the system to flourish. The members of those various groups have the freedom to interact, and thereby generate the possibility for more opportunities for stimulating experiences. The openness of this system fosters organic flourishing and growth, at an individual and social level. These ends are intrinsically worthwhile in an evolutionary sense. Democracy then is defined by its consistent transformation and expansion. The growth at the heart of democracy is predicated on education as the means through which knowledge is gained rather than lost:

And to it, as well as to life in the bare physiological sense, the principle of continuity through renewal applies. [...] Education, in its broadest sense, is the means of this social continuity of life. Every one of the constituent elements of a social group, in a modern city as in a savage tribe, is born immature, helpless, without language, beliefs, ideas, or social standards. Each individual, each unit who is the carrier of the life-experience of his group, in time passes away. Yet the life of the group goes on. (Dewey, Democracy and Education 76)

The mission of education is continuity through renewal. This is accomplished thanks to the transfer of knowledge and meaning generated by the humanities. The shared heart of both humanities education and democracy is a commitment to individual and social growth, not for any utilitarian objective, but for its own end as an evolutionary necessity. The value of democracy and humanities education are the same.

Dewey's commitment to educational innovation extended far beyond the written page. As can be inferred from his philosophy, generating lived experience according to the pedagogical principles he articulates is a necessary condition for the coherence of his system. There are three famous examples of Dewey's incursions into hands-on teaching practice directed towards specifically democratic, progressive purposes: Hull House in Chicago, The New School for Social Research in New York, and the University of Chicago Laboratory School. All three of these 
Humanities education, and education in general, is for Dewey a tool by which society can ensure the proper transfer of knowledge and meaning from one generation to the next. That is to say, it is a manifestation of social survival in an evolutionary sense. The disruption of that transfer, then, is tantamount to social suicide. Dewey's ideas help clarify the stakes in this debate, and to better understand how the current crisis has come to be. His pragmatism also serves to chart a path forward, since it obliges us to answer a simple question: How do we fix the problem for the future? How do we turn back the assault? 
institutions were guided from the start by a commitment to democracy as an ethical ideal, and education as a practical and multi-dimensional way to enact lasting social reform, specifically in combatting inequality, be it economic, racial, or gender-based.

Hull House, which was the US's first settlement house (modeled after Toynbee Hall in London), was founded in 1889 by Jane Addams and Ellen Gates Starr. Dewey served on Hull House's first board of trustees and also taught classes there. Hull House was primarily focused on providing education and recreational facilities for European immigrant women and children. As a settlement house, it housed resident social reformers from predominately middle-class backgrounds who were committed to the idea of shared space and public zones of interaction as a way to foster equality and, by extension, the expansion of democracy's premises. It was particularly driven to promote and expand gender equality, and many of its residents became notable champions of the suffragette movement.

In an effort to put forward a pragmatically rigorous answer to the challenge at hand, we will turn now to a real-world example of humanities education in action that is not as widely recognized as the three institutions just mentioned, and examine how it embodies the ideas expressed in Democracy and Education. In 1887 Jane Addams, one of the founders of Hull House, visited a small school in San Sebastián, in the north of Spain. Upon touring the school and becoming acquainted with its founders, she remarked: "The school has evoked and at the same time filled a wonderful opportunity in Spain and should have the cooperation of all women interested in the higher education of women" (Mount Holyoke College).

\section{While IIE's genesis predates the publication of Democracy and Education, it deserves to be recognized as an embodiment of the educative principles proposed there, perhaps to a greater degree than the institutions already mentioned that were designed by Dewey.}

The school Addams visited was The North American School, which in 1892 would be incorporated and renamed the International Institute for Girls in Spain, commonly known as the International Institute (IIE). While IIE's genesis predates the publication of Democracy and Education, it deserves to be recognized as an embodiment of the educative principles proposed there, perhaps to a greater degree than the institutions already mentioned that were designed by Dewey. This is because IIE engaged and engages its students still at a trans-national level of interaction, outside of the direct oversight of the state's educational bureaucracy, be it the U.S. or Spain. Even more importantly, the de facto multicultural nature of IIE enhances the dynamics of the liberal humanities classroom envisioned by Dewey. As Leonard J. Wak argues in his article "Rereading Democracy and Education Today: John Dewey on Globalization, Multiculturalism, and Democratic Education," the nature of democracy as defined by Dewey, its fundamental drive for 
expansion as it incorporates heterogeneous groups within its praxis, necessarily implies that the model of the nation-state will eventually be superseded. This evolution is firmly rooted in education: "The democratic project of humanity must advance beyond the nation-state. But it must first search for educational means conducive to such a transnational democratic order within the existing (national) order" (Wak 30). IIE is, in many ways, a site of enactment of those means, since it operates as a space of shared experience across national, cultural, and institutional boundaries.

William Gulick and his wife, Alice Gordon Gulick, were Protestant missionaries from Boston who came to San Sebastián in 1871, two years after the Spanish constitution of 1869 decriminalized the practice of religions other than Catholicism. The Gulicks were educators as well as missionaries. Alice, a graduate of Mount Holyoke College in Massachusetts, was committed to providing expanded access to education for Spanish girls, who at the time were severely underserved by the state in that regard. Gulick was a tireless worker and a relentless fundraiser for what was her chief aspiration: the construction of a Mount Holyoke in Madrid, where girls could receive a superior education that included cohabitation, and benefit from the best of America's educational methods, materials, and instructors. The women's college model, most notably represented by the Seven Sisters colleges of the Northeast, heavily guided the pedagogical approach of the Gulicks. As Carmen de Zulueta notes in her book Misioneras, feministas, educadoras: Historia del Instituto Internacional (1984), the school in San Sebastián utilized a methodology that was considered quite radical at the time:

Las estudiantes no se aprenden los textos del curso de memoria, simplemente para pasar el examen, sino que se utiliza la enseñanza práctica en los cursos de ciencias naturales, con el uso del laboratorio o las excursiones al campo para conocer la naturaleza de primera mano.(111)

This kind of experiential learning represented a dramatic departure from orthodox Spanish instruction; the fact that it was being offered to girls made it revolutionary.

The other central force behind the pedagogical practice of the Gulicks' school in San Sebastian was the primary role given to their faith, which they saw as an intrinsic feature of the education they provided. However, in order for the Gulicks to procure the land on which their longsought-after institution would be built, they had to incorporate it as a secular corporation, since it was illegal for a religious community to own Spanish property. This legal requirement would have a profound impact on the identity of the IIE in the years to come.

Upon the IIE's relocation to the capital, and prior to the completion of what would become known as the Alice Gulick Memorial Hall in 1912, at Miguel Ángel, 8, in Madrid, the Gulicks began a relationship with Institución Libre de Enseñanza, which was formed in 1876 following the Spanish government's curtailing of academic freedom for university professors in 1875. The group, led by Giner de Ríos, Gumersindo de Azcárate, and Manuel Bartolomé Cossío, consisted of academics and instructors who had been marginalized for their refusal to submit to censorship. This organization became the fulcrum for progressive educational reform in Spain over the coming decades, and the International Institute maintained a close collaborative relationship with them throughout this time. 
The Institución was from the start greatly sympathetic to the Gulicks' aspirations, and laid the groundwork for a fruitful partnership when the IIE moved to Madrid in 1903 by facilitating the purchase of properties for IIE on Calles Miguel Ángel and Fortuny, only a short walk from the ILE's headquarters on what is now Paseo del General Martínez Campos. The reason for their affinity was a shared commitment to liberal democratic ethics through education:

Para los institucionistas, defensores de la educación femenina y de la tolerancia religiosa, el Instituto Internacional representaba la realización de un sueño. Nunca habían vivido en España protestantes y católicas bajo un mismo techo y en complete armonía.(173)

The dual ideals of religious and gender equality in education, made manifest in practice through the boarding school model employed by the Gulicks, provided a powerful example for the ILE to follow.

In 1907 the Spanish state, now amenable to forward-thinking pedagogical innovation of the type pioneered by ILE, formed the Junta para Ampliación de Estudios e Invesitgaciones Científicas. The Junta was directly inspired and shaped by the disciples of Giner de Ríos and the Institucionistas:

El propósito de la Junta fue realizer en una escala nacional y con fondos del Estado lo que Giner

y la Institución se habían esforzado pos conseguir durante muchos años, dentro de un grupo limitado: la formación total del ser humano. La educación official, memorística y medieval en sus métodos, no la consigue. [...] [L]a Junta siguió la estrategia que en el siglo XIX había seguido la École des Hautes Études de París: "Establecer la investigación fuera de las universidades como el mejor medio para reformarlas".(191)

The impulse to look beyond the pre-existing (and largely sub-standard) Spanish academic structures in search of more fertile ground for educational innovation meant an enhanced role for the IIE in the Junta's reforms, since IIE boasted high-quality facilities, materials, and instructors, all of which were made available in some fashion for Spanish educators interested in improving Spanish education. Most importantly, there was recognition by key figures within the IIE that the progressive initiatives proposed by the Junta would result, if enacted, in a major step forward for Spanish culture and society.

The most noteworthy figure, and the one most crucial to the collaboration that would mark IIE's most socially significant period, was Susan Huntington Vernon, director of the IIE from 1910-1916. It was Huntington who pushed the IIE to accept a more secular identity, one in harmony with its legal status. And it was Huntington who vociferously endorsed and argued for a partnership with the Junta, in order to amplify IIE's impact on Spanish educational policy, alleviate budget concerns, and make manifest the spirit of international cooperation that existed in the West during the period surrounding the First World War. This relationship was instrumental in the formation of two institutions whose legacies have had long-lasting effects on Spanish society: the Residencia de Señoritas, formed in 1915, and the Instituto-Escuela, formed in 1918. The Residencia de Señoritas was formed five years after the Residencia de Estudiantes in 1910, another initiative of the Junta. Both were modeled on the British colleges Oxford and Cambridge; both had tremendous success in fomenting the expansion of higher education to a broad section 
of Spanish society. The Residencia de Señoritas, directed by María de Maetzu, a former instructor at IIE, rented its facilities from the International Institute, and many of its instructors and students moved between the two institutions. The same was true for the Instituto-Escuela, which was also housed on IIE grounds.

Both the Residencia de Señoritas and the Instituto-Escuela were examples of applied experimentation in both social and educational policy. The Residencia, and the Grupo de Niñas formed in 1918 as its secondary school, had a profound impact on female education in Spain, as girls received access, thanks in large part to the IIE, to facilities like laboratories and libraries, materials, and instructors, all of which had previously been denied to them. The Instituto-Escuela was created in 1918 to absorb both the Grupo de Niñas as well as the Grupo de Niños, the corresponding school for the Residencia de Estudiantes. The Instituto-Escuela was co-educational, and highly experimental in its methodologies: there were no textbooks, no exams, and no grades of any kind. The students were required to compose reaction essays to the lessons taught in their notebooks, and participated in a wide array of practical, hands-on learning, including laboratory work and map-making. There was a heavy component of art instruction, with emphasis given to its execution rather than its contemplation, as well as folk music appreciation and sport. Finally, students were sent on many diverse field trips throughout Spain, for varying lengths of time.

The Residencia de Señoritas and the Instituto-Escuela, both invested in promoting student habitation as a fundamentally important part of the educational experience, derived a great deal of inspiration from the IIE. In the context of this paper, it must be emphasized that the IIE's dedication to cohabitation for girls of different nationalities and faiths represented a titanic achievement in education in Spain. The space allocated for learning extended beyond the classroom to include the entire field of experience, all of which was recognized as part of a student's development.

The shift in IIE's identity from a Protestant,American girls boarding school, to an integral partner in liberal Spain's push for educational reform, one that de-emphasized its religious mission for a mission guided by social improvement and equality, regardless of faith, did not go internally uncontested. Many of the IIE's board of directors in Boston felt that such a close association with the Junta would be a disaster for IIE, as the Spanish state institution would absorb and erase the school Alice Gulick had worked so hard to create.

Susan Huntington disagreed with this opinion. She appreciated the momentous opportunity available to IIE in 1915. She recognized that the institution's autonomy, even its integrity, were secondary considerations compared to the role it stood to assume in a more fluid dynamic with other institutions guided by similar, if not identical, aspirations. The pursuit of such an institutional network was motivated by the desire for expansion and evolution, for educational reform that flourished outside of the traditional classroom, protected from constrictive bureaucracy and free to pursue radical solutions to deep social problems. This was a definitively liberal, democratic, and humanistic phenomenon. The power of these interlocking networks operating in a practical space of communities flexible and innovative enough to react pragmatically to problems in real time represented and represents a bulwark against the forces that devalue the humanities, and democracy in turn. By working across institutions and institutional boundaries, this network of progressive educators was able to instantiate humanities education that defied entrenchment 


\section{[Susan Huntington] appreciated the} momentous opportunity available to IIE in 1915. She recognized that the institution's autonomy, even its integrity, were secondary considerations compared to the role it stood to assume in a more fluid dynamic with other institutions guided by similar, if not identical, aspirations. The pursuit of such an institutional network was motivated by the desire for expansion and evolution, for educational reform that flourished outside of the traditional classroom, protected from constrictive bureaucracy and free to pursue radical solutions to deep social problems. This was a definitively liberal, democratic, and humanistic phenomenon. 
and restriction, while embracing heterogeneity, multiculturalism, and transnationalism. In this way, the history of the International Institute in Spain, and in particular its involvement in the Spanish educational reforms of the early $20^{\text {th }}$ century, serves as a compelling example of Dewey's principles in action.

The assault on the humanities is not simply a hyperbolic reaction to market realities from within the modern academy. It is a statement of fact that reflects one of the defining educational and social challenges of our time. In order to resist this assault we must recover the shared space of participatory democracy and liberal humanism, and so circumvent the digital enclaves that have depleted our social capital. It is only through the recognition of the value of humanities education that society will be capable of renewing that bridging capital, and with it the continuity of our democratic foundations.

\section{References}

Delany, Ella. “Humanities Studies Under Strain Around the Globe." The New York Times. 1 Dec. 2013.

Dewey, John. Democracy and Education. Penn State University, 2001.

--- Experience and Nature. Allen \& Unwin, Ltd. 1929.

De Zulueta, Carmen. Misioneras, feministas, educadores: Historia del Instituto Internacional. Madrid: Editorial Castalia, 1984.

Kaminsky, Jack. "Dewey's Defense of the Humanities." The Journal of General Education, vol. 9, no. 2, 1956, pp. 66-72.

Pariser, Eli. The Filter Bubble: What the Internet is Hiding from You. Penguin Books, 2011.

Pérez-Ibáñez, Ignacio. “Dewey's Thought on Education and Social Change." Journal of Thought, vol.52, no. 3/4, 2018, pp.19-31.

Piñón Varela, Pilar. "El Instituto Internacional y el Instituto-Escuela: Una Colaboración Pionera en España en el Terreno de la Educación Internacional." Laboratorios de La Nueva Educación en el Centenario del Instituto-Escuela. Acción Cultural Española y la Residencia de Estudiantes, 2019.

Putnam, Robert. Bowling Alone: The Collapse and Revival of American Community. Simon and Schuster, 2000.

Waks, Leonard J. "Rereading Democracy and Education Today: John Dewey on Globalization, Multiculturalism, and Democratic Education." E\&C Education and Culture, vol. 23, no.1, 2007, pp. 27-37. 